\title{
URGENSI ETIKA BISNIS DALAM MENGAKOMODIR KETERTIBAN \\ PEMASARAN PERUSAHAAN PERIKLANAN (TINJAUAN YURIDIS \\ UNDANG-UNDANG NOMOR 32 TAHUN 2002 TENTANG PENYIARAN)
}

\author{
Ahmad Yakub Sukro; Andi Tri Haryono \\ Universitas PandanaranSemarang \\ yakub.sukro@gmail.com; triharyonoandi@gmail.com
}

\begin{abstract}
Abstrak
Iklan merupakan bagian yang tak terpisahkan dalam meningkatkan daya beli masyarakat dari masa ke masa. Melalui iklan, produk dapat lebih mudah dikenal masyarakat dengan alur komunikasi dan pesan yang disampaikan ke masayarakat melalui jasa periklanan. Masalah iklan dalam dunia industri dewasa ini tidak mementingkan norma-norma dipatuhi masyarakat dan lebih menabrak batasan yang telah ditetapkan pemerintah melalui regulasi Undang-Undang Nomor 32 Tahun 2002, karena semua itu demi ketatnya persaingan bisnis.Iklan yang ditayangkan atau ditampilkan sudah sepatutnya harus sesuai dengan fakta, termasuk kualitas dari produk, harus bersifat tidak boleh menyesatkan dari apa yang dipromosikan dan tidak boleh berbenturan pada norma kesusilaan ataupun kesopanan dimasyarakat serta tidak boleh mengandung unsur sara yang menyebabkan terjadinya perpecahan dimasyarakat atau runtuhnya persatuan dan kesatuan antar golongan.Etika bisnis memposisikan dalam ruang lingkup bisnis perikalanan suatu produk yang mana dalam mempromosikan suatu produk kepada masyarakat tetap mematuhi koridor yang ada sehingga tidak ada yang dirugikan dari suatu bentuk promosi dan tidak membuat perpecahan di masyarakat. Untuk itu, melalui suatu prinsip dalam kerangka teori etika bisnis dibangunlah kerangka kepatuhan untuk tetap dalam koridor yang sehat dan unggul untuk aktivitas periklanan, prinsip tersebut yakni prinsip otonomi, prinsip kejujuran, prinsip keadilan, prinsip saling menguntungkan (mutual benefit principle), dan prinsip integritas moral.Secara regulasi, pemerintah telah mengatur mengenai batasanbatasan dalam periklanan melalui Pasal 36 ayat 1,3,4,5,6, dan Pasal 46 ayat 3,4,5,6 Undang-Undang 32 Tahun 2002 Tentang Penyiaran. Untuk itu seluruh pelaku usaha dalam mengiklankan suatu produk wajib patuh dan taat pada regulasi tersebut. Selain itu dalam pencegahan dan penindakan terhadap pelanggaran dari ketentuan Undang-Undang 32 Tahun 2002 Tentang Penyiaran tersebut, Undang-Undang mengamatkan kepada Komisi Penyiaran Republik Indonesia untuk menindak tegas segala bentuk ancaman dan pelanggaran yang ada.
\end{abstract}

Kata kunci: iklan, etika bisnis, hukum penyiaran. 


\section{A. Pendahuluan}

Secara umum, perusahaan memiliki fungsi yakni fungsi produksi dan fungsi distribusi. Dari kedua fungsi tersebut, dalam upaya mencapai tujuan perusahaan dalam meningkatkan fungsi distribusi melalui bentuk penjualan produk untuk dikonsumsi oleh masyarakat perlu adanya pengenalan kepada masyarakat agar terciptanya trend tersendiri di kalangan masyarakat sebagai sumber market utama. Iklan dan Promosi merupakan bagian yang tak terpisahkan dari sistem ekonomi dan kemasyarakan dewasa ini. Melalui iklan, sistem komunikasi terbangun dan itu merupakan langkah penting bagi perusahaan tidak saja bagi produsen atas barang atau jasa yang diproduksi tetapi juga bagi konsumen selaku pengguna dari barang atau jasa yang telah diproduksi.

Kemampuan dari iklan dan promosi melalui berbagai metode merupakan langkah penting yang dilakukan dalam menyampaikan pesan kepada konsumen menjadikan kedua bidang tersebut memegang peran sangat penting bagi keberhasilan perusahaan dalam tumbuhkembangnya dan dalam tujuan utamanya yakni mencari laba sebanyak-banyaknya. Berbagai bentuk perusahaan dalam menjalankan kegiatan usahanya mulai dari sektor industri pengolahan, industri manufaktur, industri elektronik, industri telekomunikasi, industri migas, dan lain sebagainya dalam kapasitas jangkauan distribusi skala lokal, nasional, regional maupun internasional mengandalkan iklan dan promosi untuk membantu dan menunjang dalam memasarkan barang dan jasa serta mengenakan produknya kemasyarakat sehingga masyarakat memiliki daya beli pada produk yang diproduksi oleh perusahaan tersebut.

Pada sistem ekonomi yang berlandaskan pada pasar, konsumen semakin mengandalkan iklan dan bentuk promosi lainnya untuk mendapatkan informasi yang akan mereka gunakan untuk membuat keputusan apakah akan membeli suatu produk ataukah tidak. Semakin meningkat pengeluaran (belanja) iklan dan promosi yang dilakukan peusahaan menjadi bukti bahwa pentingnya iklan dan promosi. ${ }^{1}$ Sementara bagi masyarakat selaku konsumen dari subjek iklan dan promosi yang dilakukan oleh perusahaan merupakan sarana informasi dalam

\footnotetext{
${ }^{1}$ Morissan, M.A,Periklanan: Komunikasi Pemasaran Terpadu,.(Jakarta : Kencana, 2001). Hal. 1.
} 
bentuk mengethaui keunggulan dan kekurangan terhadap suatu produk yang ditawarkan. Namun nyatanya, banyak pelaku usaha yang menjual produk tidak sesuai dengan apa yang dipromosikan, menjual produk tanpa dilengkapi infomasi yang jelas atau bahkan menjual produk yang sudah tidak layak untuk dikonsumsi ataupun mengandung konten pornografi dan mengeksploitasi bentuk tubuh wanita sebagai sarana untuk konsumsi masyarakat.

Selain itu juga banyak dari iklan dan promosi yang menampilkan konten yang menyesatkan atau tidak sesuai dengan kualitas produk barang dan jasa yang ditawarkan oleh perusahaan melalui berbagai media diantaranya media cetak, media eletronik berbentuk visual ataupun suara dan media laian dalam dunia maya berbasis internet. Dari berbagai ketentuan yang banyak berbenturan dari aturan tidak tertulis tersebut mengenai kualitas ataupun kuantitas dari produk yang ditawarkan melalui sisten promosi periklanan juga kerap ditemui konten-konten yang bertentangan dengan ketentuan peraturan yang telah ditetapkan oleh Komisi Penyiaran Indonesia selaku otoritas yang berwenang.

Untuk itu, iklan yang ditayangkan atau ditampilkan sudah sepatutnya harus sesuai dengan fakta, termasuk kualitas dari produk, harus bersifat tidak boleh menyesatkan dari apa yang dipromosikan dan tidak boleh berbenturan pada norma kesusilaan ataupun kesopanan dimasyarakat serta tidak boleh mengandung unsur sara yang menyebabkan terjadinya perpecahan dimasyarakat atau runtuhnya persatuan dan kesatuan antar golongan. Masalah iklan dalam dunia industri jika produk tidak memiliki kekuatan untuk meyakinkan khalayak, sehingga iklan harus bertumpu kepada kekuatan kata-kata dan materi informasi.

Metode penelitian dalam suatu karya ilmiah secara umum merupakan cara yang digunakan dalam melakukan analisa-analisa terhadap suatu pokok permasalahan sehingga dapat diketahui langkah-langkah dalam mencari alternatif penyelesaian permasalahan tersebut. Sehingga penelitian ini dapat diketahui bahwa fungsi dari penelitian tersebut adalah untuk mendapatkan kebenaran. ${ }^{2}$ Penelitian ini ditinjau dalam sisi hukum dan ekonomi, untuk itu pisau analisis teoritis di pakai dari teori hukum dan teori ekonomi, selanjutnyapenelitian

${ }^{2}$ Peter Mahmud Marzuki, Penelitian Hukum, (Jakarta: Kencana, 2013), Hal 20. 
ini tergolong dlam jenis penelitian normatif (doctrinal). Penelitian doktrinal adalah penelitian-penelitian atas pemikiran yang dikonsepsikan dan dikembangkan atas dasar doktrin yang dianut sang pengkonsep dan /atau sang pengembangnya. $^{3}$ Sedangkan pengertian lain mengenai penelitian normatif (doctrinal) adalah suatu prosedur penelitian ilmiah untuk menemukan kebenaran berdasarkan logika keilmuan dari sisi normatif. ${ }^{4}$

\section{B. Pembahasan}

\section{Periklanan Terhadap Produk Perusahaan Dalam Etika Bisnis}

Salah satu profesi yang menjadi banyak pilihan adalah berbisnis, dimana hal tersebut merupakan kegiatan yang menghasilkan dan menjual produk dan jasa yang dibutuhkan konsumen pada tingkat keuntungan tertentu. Dan periklanan merupakan salah satu bagian yang tidak terpisahkan dari aktifitas bisnis modern saat ini karena iklan memainkan peranan yang sangat penting untuk menyampaikan informasi tentang produk kepada masyarakat. Kata iklan (advertising) berasal dari bahasa Yunani, adapun secara harfiah pengertian iklan yakni semua bentuk aktivitas untuk mengahdirkan dan mempromosikan ide, barang atau jasa secara non personal yang dibayarkan oleh sponsor tertentu. ${ }^{5}$ Sedangkan menurut Etika pengertian iklan adalah pesan komunikasi pemasaran atau komunikasi publik tentang sesuatu produk yang disampaikan melalui sesuatu media, dibiayai oleh pemrakarsa yang dikenal serta ditujulan kepada sebagian atau seluruh masyarakat. ${ }^{6}$

Dalam dunia bisnis, iklan merupakan satu kekuatan yang dapat digunakan untuk menarik sebanyak-banyaknya. Penekanan utama iklan adalah akses informasi dan promosi dari pihak produsen kepada konsumen. Iklan pada hakikatnya merupakan salah satu strategi pemasaran yang dimaksudkan untuk mendekatkan barang yang hendak dijual kepada konsumen, dengan kata lain

\footnotetext{
${ }^{3}$ Ibid. halaman. 147 .

${ }^{4}$ Johnny Ibrahim, Teori\&Metodologi Penelitian Hukum Normatif, (Malang ; Bayu Publishing, 2012),Hal. 57.

${ }^{5}$ Mabarroh Azizah. 2013. Etika Perilaku Peiklanan Dalam Bisnis Islam. Jurnal Ekonomi Syariah Indonesia (JESI) Volume III, No. 1 Juni 2013/1434 H. Hal. 39

${ }^{6}$ Ibid. Hal. 39.
} 
mendekatkan konsumen dengan produsen. Sasaran akhir seluruh kegiatan bisnis adalah agar barang yang telah dihasilkan bisa dijual kepada konsumen. Secara positif iklan adalah suatu metode yang digunakan untuk memungkinkan barang dapat dijual kepada konsumen. Serta iklan sebagai salah satu alat pemasaran melalui promosi merupakan proses komunikasi yang bertujuan mempengaruhi minat calon pembeli sehingga mampu memasarkan.

Dalam dunia bisnis yang menjadikan pasar sebagai pedoman awal atau acuan dasar dalam konsepsi alur kegiatan perekonomian masih mengandalkan periklanan atau bentuk promosi lainnya sebagai alat utama dalam membangkitkan garah masyarakat untuk memiliki daya beli terhadap suatu produk atau jasa yang dihasilkan oleh perusahaan. Lebih lanjut penjelasan sarana iklan dalam membangkitkan gairah dari konsumen dalam memberi produk dari perusahaan merupakan salah satu fungsi dari iklan sendiri, disisi lain iklan atau promosi merupakan satu kesatuan informasi yang akan digunakan oleh suatu perusahaan mengenalkan dan berinteraksi lebih dekat dengan masyarakat dalam memberikan pengetahuan informasi atas produk sehingga konsumen mengetahui detail dan spesifikasi lengkap atas produk yang ditawarkan tersebut.

Bisnis yang baik (good business) tidak saja mencari keuntungan semata dari kegiatan usahanya, akan tetapi bisnis yang baik yakni harus juga berperilaku yang sesuai dengan norma-norma moral, perilaku dapat dinilai baik ketika memenuhi standar etis dari ketentuan dasar masyarakat yang menjadi pedoman berperilaku ataupun bertindak. Berperilaku tersebut tidak hanya menyangkut dari tindakan dasar perusahaan dalam melakukan suatu bentuk produksi atas barang ataupun jasa, serta dalam kegiatan distribusi pun perusahaan harus senantiasi mematuhi ketentuan ataupun norma dasar dalam masyarakan secara tidak tertulis maupun ketentuan pada hukum positif yang telah dibuat untuk menciptakan ketertiban dan kemanan dalam skala nasional kaitannya dengan kegiatan perekonomian. Untuk itu prinsip-prinsip etika sangat penting bagi bisnis dengan harapan dalam berbisnis mendapatkan keselarasan, keamanan dalam berusaha, kepercayaan oleh masyarakat dalam setiap produknya serta kemajuan atau 
perkembangan yang signifikan dari organisasi keperusahaan dengan adanya pedoman prinsip-prinsip dasar etika bisnis.

Peran iklan dalam kegiatan bisnis juga senantiasa harus memiliki etika dalam melakukan promosi atau pengenalan produk yang dihasilkan oleh perusahaan. Etika sendiri dianggap penting karena didalamnya terkait aturan dasar, pedoman dalam bertindakn dan norma-norma yang menjadi acuan masyarakat dalam melakukan penilaian terhadap suatu klausa tertentu apakah hal itu baik atau buruk, sesuai atau tidak sesuai, dan layak atau tidak layak maupun patut atau tidak patut. Untuk itu sejatinya dalam penerapan etika terhadap suatu bentuk tindakan iklan dalam mempromosikan produk kemasyarakat harus paham benar norma yang yang menjadi pandangan masyarakat tersebut secara tidak tertulis dan norma yang menjadi ketentuan pemerintah secara tertulis, dari kedua hal tersebutlah nantinya akan ditarik suatu garis lurus bahwa keduanya merupakan satu kesatuan yang tidak terpisahkan dalam melakukan aktivitas bisnis pada kegiatan promosi produk. Ada ciri-ciri khas iklan yang dipaparkan oleh Sobagyo Harry Affandi, yaitu :

a. Publik presentation (penyajian di muka umum), iklan merupakan suatu sarana komunikasi yang sangat bersifat umum.

b. Pervasivees (penyerahan menyeluruh), iklan merupakan medium yang diserap secara menyeluruh dan memungkinkan pihak perusahaan untuk menanggulangi pesannya itu berulang-ulang.

c. Expresivenes (daya ungkap yang kuat), iklan memberikan peluang untuk menampil perusahaan serta produknya dengan cara yang amat mengesankan dengan penggunaan cetakan, bunyi dan warna secara pandai

d. Impreseonality (kurang kepribadian), iklan senantiasa bersifat umum, daya meyakinkan dan mengungkapkan masih kurang.

Oleh karena itu sudah semestinya kegiatan promosi pun harus mengenal dan menjadi prinsip-prinsip etika bisnis sehingga suatu perusahaan memiliki citra yang baik dipandangan masyarakat selaku subjek konsumen atas produknya dan keamanan serta kekondusifan atas usahanya karena apa yang dilakukan

${ }^{7}$ Ibid. Mabarroh Azizah. Hal 39. 
perusahaan tersebut sejatinya tidak menabrak ketentuan dasar yang telah ditetapkan pemerintah melalui ketentuan peraturan dan kebijakan sebagai ketentuan hukum tertulis. Menurut Redi Panuju ${ }^{8}$ bahwa kegiatan mencari etika bisnis menyangkut 4 kegiatan yaitu : (1) menerapkan prinsip-prinsip etika umum pada khususnya atau praktek-praktek khusus dalam bisnis menyangkut apa yang dinamakan meta-etika, (2) apakah perilaku dan tindakan yang dinilai secara etis atau tidak etis pada individu dapat dikenakan pada organisasi atau organisasi bisnis, (3) menyoroti moralitas sistem ekonomi pada umumnya serta sistem ekonomi suatu negara pada khususnya, (4) meluas melampaui bidang etika, menelaah teori ekonomi dan organisasi.

Prinsip-prinsip etika bisnis seperti apa yang dikemukakan oleh Sony Kerap sebagai berikut : (1) Prinsip otonomi, adalah sikap dan kemampuan manusia untuk mengambil keputusan dan bertindak berdasarkan kesadarannya tentang apa yang dianggapnya baik untuk dilakukan. (2) Prinsip kejujuran, terdapat tiga ruang lingkup kegiatan bisnis yang bisa ditunjukkan secara jelas bahwa bisnis tidak akan didasarkan atas kejujuran, yaitu : (a) jujur dalam pemenuhan syarat-syarat perjanjian kontrak, (b) kejujuran dalam penawaran barang atau jasa dengan mutu dan harga yang sebanding, (c) jujur dalam hubungan kerja intern dalam suatu perusahaan, (3) Prinsip keadilan, menuntut agar setiap orang diperlakukan secara sama sesuai dengan aturan yang adil dan sesuai kriteria yang rasional obyektif, serta dapat dipertanggungjawabkan, (4) Prinsip saling menguntungkan (mutual benefit principle), menuntut agar bisnis dijalankan sedemikian rupa sehingga menguntungkan semua pihak. (5) Prinsip integritas moral, terutama dihayati sebagai tuntutan internal dalam diri pelaku bisnis atau perusahaan, agar perlu menjalankan bisnis dengan tetap menjaga nama baik pimpinan/orang-orangnya maupun perusahaan. ${ }^{9}$

\section{Penerapan Tanggung Jawab Perusahaan Pada Perikalanan Dalam} Dimensi Teoritis Etika Bisnis

\footnotetext{
${ }^{8}$ Redi Panuju,Etika Bisnis,(Jakarta : Gramedia Widiasarana Indonesia, 1995). Hal 7.

${ }^{9}$ Sony Keraf,Etika Bisnis; Tuntutan dan Relevansinya,(Jakarta : Kanisius, 1998). Hal 56.
} 
Pelaku bisnis mempunyai fungsi yang sangat penting dalam kehidupan bermasyarakat. Pelaku bisnis adalah organ masyarakat yang mempunyai dua fungsi sekaligus. Pertama sebagai pemasok semua kebutuhan masyarakat mulai dari kebutuhan primer sampai kebutuhan sekunder dan tersier. Kedua, sebagai menyerap tenaga kerja masyarakat. Pelaku bisnis atau pelaku ekonomi di Indonesia sangat beragam, mulai dari bentuknya, organisasinya, maupun statusnya, bidang usaha dan kemampuan usahanya. Pelaku ekonomi adalah setiap subyek yang melakukan kegiatan ekonomi. Subyek yang melakukan kegiatan bisnis dapat meliputi perorangan, kumpulan orang, organisasi ekonomi, korporasi atau badan usaha. ${ }^{10}$

Secara eksplisit pelaku bisnis merupakan suatu profesi yang merupakan lahan pekerjaan bagi seorang pebisnis dalam menjalankan usahanya. Profesi adalah pekerjaan yang dilakukan sebagai kegiatan pokok untuk menghasilkan nnafkah hidup dan yang mengandalkankan suatu keahlian. ${ }^{11}$ Selaku kegiatan ekonomis, bisnis selalu sudah dipraktekkan sepanjang sejarah tersedia pelatihan, pendidikan dan penelitian khusus untuk memperoleh ketrampilan dibidang itu. Dari hal tersebut menjadikan bisnis menjadi suatu profesi khusus yang dilakukan dengan meggunakan keahlian dan ketrampilan dalam bidang tertentu untuk mencapai tujuan bisnis yang etis salah satunya. Tujuan etika bisnis bukan mengubah keyakinan moral seseorang, melainkan untuk meningkatkan keyakinan itu sehingga orang percaya pada diri sendiri dan akann memberlakukannya di bidang bisnis. ${ }^{12}$

Seperti etika terapan pada umumnya, etika bisnis dapat dijalankan pada tiga taraf, (a) taraf makro, (b) taraf meso dan (c) taraf mikro, etika bisnis pada taraf makro, mempelajari aspek-aspek moral dari sistem ekonomi sebagai keseluruhan dan lebih menyoroti pada skala besar. Etika bisnis pada taraf meso lebih menyoroti masalah-masalah etis di bidang organisasi antara lain perusahaan, serikat buruh, lembaga konsumen, perhimpunan profesi, sedangkan pada taraf

\footnotetext{
${ }^{10}$ Bambang Eko Turisno,Tanggung Jawab Pelaku Bisnis,(Semarang : Badan Penerbit Universitas Diponegoro, 2011). Hal 14.

${ }^{11}$ Sony Keraf. Op Cit. Hal. 44.

${ }^{12}$ O.P. Simarangkir,Etik dan Moral Perbankan,(Jakarta : Ind-Hill CO, 1983). Hal. 31
} 
mikro etika bisnis lebih memfokuskan pada hubungan antara individu dengan bisnis, yaitu tanggung jawab etis dari karyawan dengan majikan, bawahan dengan manager, produsen dengan konsumen, pemasok dengan investor. ${ }^{13}$

Etika bisnis secara khusus menyangkut empat macam kegiatan, yakni diantaranya adalah Pertama, penerapan prinsip-prinsip etika umum pada kasus atau praktek-praktek khusus dalam bisnis. Pada gilirannnya akan diperoleh prinsip-prinsip etika yang khusus berlaku untuk bidang bisnis. Kedua, etika bisnis tidak hanya menyangkut penerapan prinsip-prinsip etika pada bidang kegiatan bisnis. Lebih dari itu, etika bisnis menyangkut apa yang disebut metaetika. Disini etika bisnis hendak menyoroti, seperti apakah perilaku dan tindakan yang dinilai secara etis atau tidak pada individu dapat juga dikenakan pada organisasi atau perusahaan. Ketiga, menyangkut praanggapan-praanggapan mengenai bisnis. karena bisnis dijalankan dalam suatu sistem ekonomi maka etika bisnis disini hendaknya menyoroti moralitas, sistem ekonomi umumnya serta sistem ekonomi suatu negara khususnya. ${ }^{14}$

Dalam etika profesi yang menjadi dasar dari berjalannya bisnis yang memiliki etika dan moral setidaknya ada beberapa teori yang dapat dijadikan dasar sebagai bahan analitikal dari suatu tindakan atau kegiatan bisnis yang dilakukan oleh seseorang atau badan usaha, yaitu :

a. Utilitarisme, sebagai teori etika cocok sekali dengan pemikiran ekonomi. Teori ini cukup dekat dengan cost-benefit analysis yang banyak dipakai dalam konteks ekonomi, menurut teori ini jika suatu perbuatan mengakibatkan manfaat paling besar, artinya paling memajukan kemakmuran, kesejahteraan, dan kebahagiaan masyarakat, maka perbuatan itu adalah baik, sebaliknya jika perbuatan membawa lebih banyak kerugian daripada manfaat, perbuatan itu harus dinilai buruk. Teori ini dinamai juga konsekuensialisme atau teori teleologis.

b. Deontologi, menurut teori ini yang menjadi bagi buruknya perbuatan adalah kewajiban. Yang memberikan landasan pendasaran filosofis kepada teori

\footnotetext{
${ }^{13}$ K. Bartents,Pengantar Etika Bisnis,(Yogyakarta : Kanisius, 2000). Hal. 35.

${ }^{14}$ F. Magniz Suseno,Berfilsafat Dari Konteks,(Jakarta: Gramedia, 1991). Hal 162.
} 
adalah Immanuel Kant. Menurut Immanuel Kant, suatu perbuatan adalah baik jika dilakukan karena harus dilakukan atau dilakukan karena kewajiban, lebih lanjut Immanuel Kant mengatakan bahwa suatu perbuatan adalah baik jika dilakukan berdasarkan "imperatif kategoris". Imperatf kategoris mewajibkan kita begitu saja, tak tergantung dari syarat apa pun, misalnya barang yang dipinjam harus dikembalikan, Kant mengatakan bahwa imperatif kategoris yang terkandung dalam setiap perbuatan moral bisa dirumuskan secara singkat ; Du sollst artinya engkau harus begitu saja.

c. Teori Hak, dalam pemikiran moral dewasa ini barangkali teori hak adalah pendekatan yang paling banyak dipakai untuk mengevaluasi baik buruknya suatu perbuatan atau perilaku. Menurut teori ini hak didasarkan atas martabat manusia dan martabat semua manusia itu sama, perbuatan adalah baik jika sesuai dengan hak manusia.

d. Teori Keutamaan, teori ini memandang sikap dan akhlak seseorang, tidak ditanyakan, apakah suatu perbuatan tertentu adil atau jujur atau murah hati melainkan apakah orang itu bersikap adil, jujur, murah hati, dan sebagainya. Teori ini mempunyai suatu tradisi lama yang sudah dimulai pada saat filsafat Yunani Kuno yaitu Aristoteles. Teori ini menghidupkan kembali pemikiran Aristoteles yaitu tentang virtue diterjemahkan sebagai kebajikan atau kesalehan atau keutamaan. Diantara keutamaan yang harus menandai pebisnis perorangan bisa disebut : kejujuran, fairness, kepercayaan, dan keuletan. ${ }^{15}$

Pentingnya etika profesi tidak hanya untuk pergaulan antar perorangan. Ini menyangkut landasan bagi kehadiran suatu institusi sosial di tengah masyarakat. Orientasi sosial dalam menghadirkan profesinya agar punya marwah (virgour) dan martabat (dignity) ditengah masyarakat. Semakinj banyak pihak yang berkepentingan dan memperhatikan pelaksanaan etika profesi, tentulah semakin baik bagi kehidupan masyarakat. Kesadaran dan profesional memang diharapkan, namun hendaknya etika profesi jangan diartikan secara statis dalam arti bahwa segala sesuatunya hendaknya dapat dikembalikan kepada hati nurani dari pengembann profesi itu sendiri.

\footnotetext{
${ }^{15}$ Bambang Eko Turisno. Op Cit, Hal 55-56.
} 
Terkait pertanggungjawaban secara etika bisnis terhadap pelaku bisnis dari tindakan melawan hukum ataupun norma termasuk dalam hal ini yakni iklan dalam mempromosikan produk dari perusahaan yakni orang tidak bertanggungjawab berarti segala perbuatannya, kewajiban dan apa yang harus diawasi tidak dapat dipertanggungjawabkan kepadanya. Untuk dapat dipertanggungjawabkan adalah tanggung olehnya (oleh pembuat), diperhitungkan kepadanya, dibebankan kepadanya, atau menurut ajaran kesalahan (schuldleer) dapat dipersalahkan kepadanya. Dilihat dari peristiwanya (feit), menurut Schut suatu peristiwa adalah dipertanggungjawabkan apabila seseorang terhadap peristiwa itu dapat dinyatakan bertanggungjawab. ${ }^{16}$

Bagi etika bisnis terkait periklanan dalam mempromosikan produk perusahaan harus diberdasarkan atas kode etik yang telah disepekati oleh para pengusaha yang terkumpul dalam satu wadah organisasi. Hal itu terkait mengenai kepatuhan dan iktikad baik pada hakekatnya merupakan salah satu sendi dari nilai-nilai etis yang seharusnya menjadi pedoman para pengusaha. Nilai-nilai dan norma yang berlaku bagi praktek bisnis merupakan etika bisnis. Etika bisnis ingin menjamin bahwa dalam bisnis orang-orang yang bukan hanya orang-orang bisnis tetapi juga manusia berlaku sesuai dengan martabat mereka sebagai manusia.

Tindakan yang bertentangan dengan etika bisnis tercakup sebagai perbuatan curang dan tidak beretika dalam berbisnis kaitannya untuk mempromosikan suatu produk melalui melalui media periklanan. Lebih lanjut mengenai perbuatan curang ataupun melanggar norma-norma sosial yang dihormati dan dijunjung masyarakat merupakan salah satu ruang lingkup dari perbuatan curang dalam persaingan usaha. Karena tindakan tersebut demi mendapatkan perhatian dan posisi (bergaining) atas produk yang ditawarkan akan tetapi tidak mengedepankan asas-asas dan prinsip etika bisnis.

Menurut Emy Pangaribuan, ${ }^{17}$ cakupan-cakupan dari perbuatan persaingan curang itu benarnya sangat luas karena menyangkut komplek perbuatan yang bertujuan untuk mengurangi atau menurunkan hasil perusahaan atau pengusaha

\footnotetext{
${ }^{16}$ Ibid. Bambang Eko Turisno. Hal. 57.

${ }^{17}$ Bambang Eko Turisno. 2007. Etika Bisnis. Bandung : CV. Mandar Maju. Hal. 50-51
} 
industri pihak lain untuk memperbesar keuntungan baginya sedangkan perbuatan itu seharusnya dipandang sebagai tidak diperbolehkan dalam pergaulan perniagaan atau perdagangan yang sehat. Oleh karena itu ter masuk ke dalam sifat perbuatan atau kompleks perbuatan yang dimaksud adalah semua perbuatan bersaing yang dapat dikualifikasikan sebagai perbuatan melawan hukum, perbuatan yang tidak diinginkan atau perbuatan yang tidak sepatutnya atau tidak sepantasnya atau tidak jujur didalam lingkungan masyarakat ekonomi yang menyangkut etika bisnis.

Secara aturan tertulis pedoman khusus yang menjadi batasan-batasan dalam menampilkan suatu iklan untuk mempromosikan produk yang dihasilkan oleh perusahaan yakni melalui Undang-Undang Nomor 32 Tahun 2002 Tentang Penyiaran. Undang-Undang tersebut merupakan ketentuan yang bersifat hukum positif yang bersifat terikat dan memaksa bagi siapa pun selama masih di wilayah yurisdiksi Indonesia. Dalam Peraturan tersebut dijelaskan bahwa terdapat 2 kategori iklan yakni iklan niaga dan iklan layanan masyarakat. Dari kedua bentuk iklan tersebut dapat ditampilkan untuk memberikan informasi kepada masyarakat melalui media televisi, media radio, media surat kabar ataupun media eektronik melalui website internet, dsb. Selanjunya menelisik lebih lanjut tentang konten yang harus dilaksanakan oleh perusahaan dalam menggunakan media untuk menyiarkan iklan berdasarkan Pasal 36 ayat 1,3,4,5,6, Undang-Undang 32 Tahun 2002 Tentang Penyiaran yakni :

\section{Pasal 36}

(1) Isi Isi siaran wajib mengandung informasi, pendidikan, hiburan, dan manfaat untuk pembentukan intelektualitas, watak, moral, kemajuan, kekuatan bangsa, menjaga persatuan dan kesatuan, serta mengamalkan nilai-nilai agama dan budaya Indonesia.

(3) Isi siaran wajib memberikan perlindungan dan pemberdayaan kepada khalayak khusus, yaitu anak-anak dan remaja, dengan menyiarkan mata acara pada waktu yang tepat, dan lembaga penyiaran wajib mencantumkan dan/atau menyebutkan klasifikasi khalayak sesuai dengan isi siaran.

(4) Isi siaran wajib dijaga netralitasnya dan tidak boleh mengutamakan kepentingan golongan tertentu.

(5) Isi siaran dilarang:

a. bersifat fitnah, menghasut, menyesatkan dan/atau bohong; 
b. menonjolkan unsur kekerasan, cabul, perjudian, penyalahgunaan narkotika dan obat terlarang; atau

c. mempertentangkan suku, agama, ras, dan antargolongan.

(6) Isi siaran dilarang memperolokkan, merendahkan, melecehkan dan/atau mengabaikan nilai-nilai agama, martabat manusia Indonesia, atau merusak hubungan internasional.

Dari penjelasan Pasal 36 Undang-Undang 32 Tahun 2002 Tentang Penyiaran tersebut merupakan ketentuang wajib yang harus ditaati sebagai hukum tertulis bagi siapa pun orang atau badan usaha di Indoensia dalam melakukan suatu penyiaran berbentun periklanan niaga ataupun layanan masyarakat. Secara lebih jelas lagi terkait ketentuan yang berlaku wajib menjadi pedoman oleh perusahaan dalam menayangkan informasi produk kepada masyarakat selaku konsumen melalui suatu bentuk siaran niaga. lebih lanjut dalam Pasal 46 ayat 3,4,5,6 diatur kembali mengenai siaran iklan yakni:

\section{Pasal 46}

(3) Siaran iklan niaga dilarang melakukan:

a. promosi yang dihubungkan dengan ajaran suatu agama, ideologi, pribadi dan/atau kelompok, yang menyinggung perasaan dan/atau merendahkan martabat agama lain, ideologi lain, pribadi lain, atau kelompok lain;

b. promosi minuman keras atau sejenisnya dan bahan atau zat adiktif;

c. promosi rokok yang memperagakan wujud rokok;

d. hal-hal yang bertentangan dengan kesusilaan masyarakat dan nilai-nilai agama; dan/atau

e. eksploitasi anak di bawah umur 18 (delapan belas) tahun.

(4) Materi siaran iklan yang disiarkan melalui lembaga penyiaran wajib memenuhi persyaratan yang dikeluarkan oleh KPI.

(5) Siaran iklan niaga yang disiarkan menjadi tanggung jawab lembaga penyiaran.

(6) Siaran iklan niaga yang disiarkan pada mata acara siaran untuk anak-anak wajib mengikuti standar siaran untuk anak-anak.

Ketentuan-ketentuan yang telah diatur dengan jelas tersebut merupakan norma tertulis yang harus di laksanakan dan dipatuhi oleh siapapun bila mereka ingin beriklan menggunakan jasa penyiaran media elektronik. Apabila ketentuanketentuan tersebut tidak diindahkan oleh para pelaku usaha dalam menggunakan media dalam mempromosikan produk dari perusahaan supaya diketahui informasi 
dan sepesifikasi atas produk tersebut oleh masyarakat maka yang timbul yakni sifat melawan hukum dan berakibat adanya pertanggungjawaban hukum terhadap pelaku usaha yang memanfaat media sebagai alat promosi.

Suatu perbuatan melawan hukum tidak hanya merupakan perbuatan yang bertentangan dengan Undang-Undang tetapi, juga merupakan perbuatan yang bertentangan dengan hak orang lain. atau bertentangan dengan kewajiban hukum di pelaku, atau bertentangan dengan kesusilaan dan sikap hati-hati yang dituntut dalam pergaulan masyarakat. Jadi, sekalipun seseorang atau badan usaha tidak melanggar undang-undang, atau melanggar hak orang lain, atau tidak bersikap bertentangan dengan kebiasaan, akan tetapi apabila ia tidak cukup menunjukkan sikap hati-hati dan tenggang rasa terhadap kepentingan orang lain di dalam masyarakat, maka ia telah dapat dianggap bertentangan dengan kesusilaan dan bersalah melakukan perbuatan melawan hukum. ${ }^{18}$

\section{Penutup}

Dari uraian yang dituliskan, penulis memiliki kesimpulan diantaranya adalah :

1. Bisnis yang baik (good business) tidak saja mencari keuntungan semata dari kegiatan usahanya, akan tetapi bisnis yang baik yakni harus juga berperilaku yang sesuai dengan norma-norma moral, perilaku dapat dinilai baik ketika memenuhi standar etis dari ketentuan dasar masyarakat yang menjadi pedoman berperilaku ataupun bertindak.

2. Menurut Etika pengertian iklan adalah pesan komunikasi pemasaran atau komunikasi publik tentang sesuatu produk yang disampaikan melalui sesuatu media, dibiayai oleh pemrakarsa yang dikenal serta ditujulan kepada sebagian atau seluruh masyarakat, oleh karena itu suatu badan usaha dalam melakukan bentuk promosi atas produk yang diiklankan harus (1) menerapkan prinsipprinsip etika umum pada khususnya atau praktek-praktek khusus dalam bisnis

\footnotetext{
${ }^{18}$ L.EH. Rutten, dalam Sunaryati Hartono, Pengaturan Tentang Perbuatan Curang di Bidang Bisnis (Sebagai Suatu Prnanata Hukum Untuk Menumbuhkan Iklim dan Ekonomi Yang Sehat dan Adil Berdasarkan Pancasila dan UUD 1945). yang dikutip kembali dari Loc Cit. Bambang Eko Turisno. Tanggung Jawab Pelaku Bisnis. Hal. 59
} 
menyangkut apa yang dinamakan meta-etika, (2) apakah perilaku dan tindakan yang dinilai secara etis atau tidak etis pada individu dapat dikenakan pada organisasi atau organisasi bisnis, (3) menyoroti moralitas sistem ekonomi pada umumnya serta sistem ekonomi suatu negara pada khususnya, (4) meluas melampaui bidang etika, menelaah teori ekonomi dan organisasi.

3. Terkait pertanggungjawaban secara etika bisnis terhadap pelaku bisnis dari tindakan melawan hukum ataupun norma termasuk dalam hal ini adalah iklan dalam mempromosikan produk dari perusahaan yakni orang tidak bertanggungjawab berarti segala perbuatannya, kewajiban dan apa yang harus diawasi tidak dapat dipertanggungjawabkan kepadanya. Untuk dapat dipertanggungjawabkan adalah tanggung olehnya (oleh pembuat), diperhitungkan kepadanya, dibebankan kepadanya, atau menurut ajaran kesalahan (schuldleer) dapat dipersalahkan kepadanya. Dilihat dari peristiwanya (feit), menurut Schut suatu peristiwa adalah dipertanggungjawabkan apabila seseorang terhadap peristiwa itu dapat dinyatakan bertanggungjawab. 


\section{Daftar Pustaka}

Bambang Eko Turisno, 2007,Etika Bisnis, Bandung : CVMandar Maju.

Bambang Eko Turisno, 2011,Tanggung Jawab Pelaku Bisnis, Semarang : Badan Penerbit Universitas Diponegoro.

F. Magniz Suseno, 1991,Berfilsafat Dari Konteks, Jakarta : Gramedia.

Johnny Ibrahim, 2012,Teori\&Metodologi Penelitian Hukum Normatif, Malang :

Bayu Publishing.

K. Bartents, 2000,Pengantar Etika Bisnis, Yogyakarta : Kanisius.

Mabarroh Azizah, 2013,Etika Perilaku Peiklanan Dalam Bisnis Islam, Jurnal Ekonomi Syariah Indonesia (JESI), Vol. III, No. 1, Juni 2013/1434 H.

Morissan, 2001,Periklanan: Komunikasi Pemasaran Terpadu, Jakarta: Kencana.

O.P. Simarangkir, 1983,Etik dan Moral Perbankan, Jakarta: Ind-Hill CO.

Peter Mahmud Marzuki, 2013, Penelitian Hukum, Jakarta: Kencana.

Redi Panuju, 1995,Etika Bisnis, Jakarta: Gramedia Widiasarana Indonesia.

Sony Keraf, 1998,Etika Bisnis: Tuntutan dan Relevansinya, Jakarta: Kanisius. 